Review

\title{
Wood Quality: A Perspective from New Zealand
}

\section{John Walker}

School of Forestry, College of Engineering, University of Canterbury, Christchurch, New Zealand; E-Mail: john.walker@canterbury.ac.nz; Tel.: +64-33642118; Fax: +64-33642124

Received: 13 December 2012; in revised form: 9 April 2013 / Accepted: 11 April 2013 /

Published: 22 April 2013

\begin{abstract}
Forest products are commodities and subject to cyclical trends; yet resource-hungry countries offer exporters a period of sustained growth for those with the right products. Products have their distinctive requirements, e.g., finishing timber (colour, stability), structural (strength stiffness, stability), paper (fibre length and tear strength). The failure to incorporate such key properties in radiata pine (Pinus radiata) breeding programmes has been a lost opportunity for New Zealand forestry that constrains exports. Radiata pine remains a utilitarian, undifferentiated commodity. A complementary opportunity in international markets lies in naturally-durable eucalypts grown on New Zealand's east coast drylands. These are species whose properties mimic those of the finest tropical hardwoods that are in most demand in Asian markets.
\end{abstract}

Keywords: market demand; radiata pine; durable eucalypts; corewood; structural grades; density; cultural preferences

\section{Introduction}

New Zealand is noted for the growth and size of its forest plantations, principally of radiata pine (Pinus radiata). The country is distant from major markets, yet its trade in forest products has for 50 years been dominated by bulk shipping of logs. This is unlikely to change in the foreseeable future. In part this might be attributed to a shortage of capital for wood processing, but the case is made that breeders and foresters have focused on the obvious - tree health, fast growth and a straight, single stem without which there would be no resource worth exporting-rather than the mediocre intrinsic qualities of the wood itself, especially of the corewood. The failure to address that issue prevented radiata pine from achieving its full potential, relegating it to commodity status. Past emphasis on basic density as a surrogate for hard to measure, more useful wood properties - such as stiffness, strength 
and stability - has not delivered the desired outcomes. Even if the wood quality were to be addressed immediately it will be another 35 years before a superior resource becomes available. The first part of this review examines the nature of a commodity and the properties of radiata pine in that context.

Another missed opportunity for New Zealand forestry has been the absence of fine timbers. Indeed some argue that pine can be "modified" to meet most needs. The second part of this review considers new opportunities for NZ-grown plantation species to replace the dwindling supply of tropical hardwoods for furniture and decorative interiors, especially in Asian markets where there will be 1500 million new middle-class citizens by 2050 . Hitherto the abundance of tropical woods and the desire for "named" woods has resulted in few instances of successful sawlog plantations in tropical and sub-tropical regions, where plantations are largely for pulpwood. Both Australia and New Zealand have breeding programmes that aim to deliver equivalent "named" timbers. These new species (Eucalyptus spp.) can be grown on shorter rotations than softwoods and will compete on innovation and excellence rather than on price, undergirdled by scarcity and environmental constraints.

\section{Forestry as a Commodity Business}

Gloomy predictions by the Club of Rome [1] drove massive over-investment that resulted in 20 lean years for the resource sector. In 1982 commodity stocks represented $36 \%$ of the New York S\&P index: at their nadir in 2000 they were only 6\%. Instead of shortages the world got two decades of ever-cheaper food, fuel, lumber, metals, paper and plastics - exaggerated by the peace dividend as, for example, Soviet-era mines dumped their military stockpiles on world markets. In the 1980s the EU (and others) introduced schemes to set aside around 10\% of agricultural land [2] to reduce food surpluses and lift prices at the farm gate [3]. Across commodities, industry consolidation replaced capital investment as the path to survival: there was no rush to invest and there still is not. Curiously this was not the case for forestry. New Zealand's plantations increased from $0.85 \mathrm{M}$ ha in 1980, 1.26 $\mathrm{M}$ ha in 1990 and $1.77 \mathrm{M}$ ha in 2000, before leveling off at $1.74 \mathrm{M}$ ha in 2010 [4]. Global growth in plantings has been even more dramatic, especially in Asia [5].

In early 1999 when Figure 1 was published one could make the following suppositions [6,7]: (i) that all commodities were due for sustained resurgence, and (ii) it was better to produce what Asia wanted than to compete over what it produced.

In 2000 the resource sector was at the beginning of sustained secular growth that would eclipse previous booms. Oil became a bet on the global economy, iron ore on sustained capex and infrastructure development in China; and lumber was a bet on... multiple-home ownership in a demographically ageing First World... or a low-cost $80 \mathrm{~m}^{2}$ home that comes with increased prosperity in Asia... or...?

This repricing of commodities has contributed to the sudden wealth of producers and is why Asian interests are keen to participate in both sides of the trade, scouring the world for investments, partners and security of supply. Their ambition must be to manage their overseas supply lines, and in the long-term to restrain prices. 
Figure 1. The Economist industrial commodity-price index, in real dollar terms, $1845-1850=100$. This is a narrow index (51\% foods; $49 \%$ industrial; no energy) that is rebased as demand changes and as other commodities are included. Oil, omitted from the index, has increased 10-fold since 2000. The four orange ovals marking events (e.g., War, ca. 1915) have been superimposed. Prices doubled on all four occasions [8].

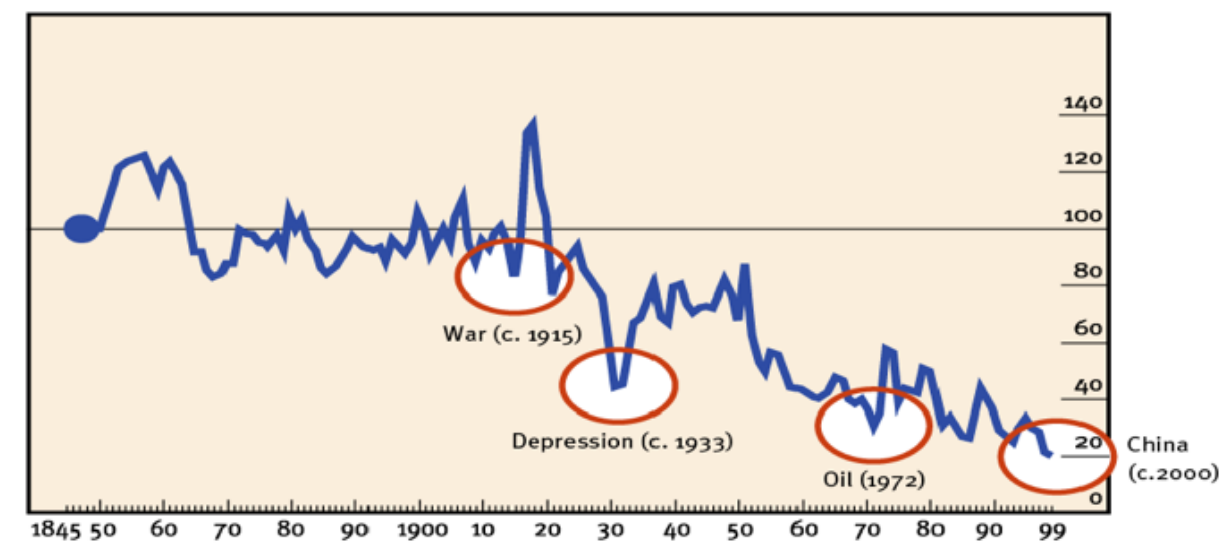

Higher prices were not just due to under investment and worn out or depleted operations. Incredibly, the arrival of China had not been acknowledged despite growing $10 \%$ per annum for 20 years. Disillusionment among producers coupled with rising demand in Asia guaranteed the future such that today the commodity boon offers New Zealand at least 10 more prosperous years before Asia sorts its resource supply lines and imposes a Walmart-like discipline on producers. Meanwhile we are on the right side of the new rule: to produce what Asia needs rather than what Asia produces. There is more competition in mobile phones and IT - threatening shrinking profits - than there is in commodities.

Yet over the last 10 years prices for forest products in the US, for example for framing timber (Figure 2), have disappointed lagging most other commodities. For NZ exporters this has been aggravated by the $50 \%$ decline in the US dollar against the NZ dollar in the last 12 years.

Fortunately demand lies elsewhere...

Increasing demand for wood from China and India alone, regardless of intrinsic properties

of the wood, justifies increasing the productivity of New Zealand plantations [9].

... and assures New Zealand of markets regardless of the properties of radiata pine: but simply producing more of the same is a questionable strategy.

Foresters plan for the long term, beyond the current boon. Whether further growth is sustainable (the Europeans are hoping so) growth is embedded in the fabric of modern societies. How forests might be used and valued is less clear, yet their future contribution to societal needs is assured. At one extreme, Gilding [10] states that resource consumption today is $1.4 \times$ that which the earth has the capacity to sustain and, with business as usual consumption, would be an impossible $5 \times$ over that limit by 2050. Contrariwise Riley [11] sees resolution as systematic innovation becomes the resource: the means of increased production will be knowledge rather than in the use of more resources and capital. 
Figure 2. Monthly Nearby Lumber (CME) prices (US\$/1000 board feet) which tracks the framing lumber composite price in the United States, with no adjustment for inflation.

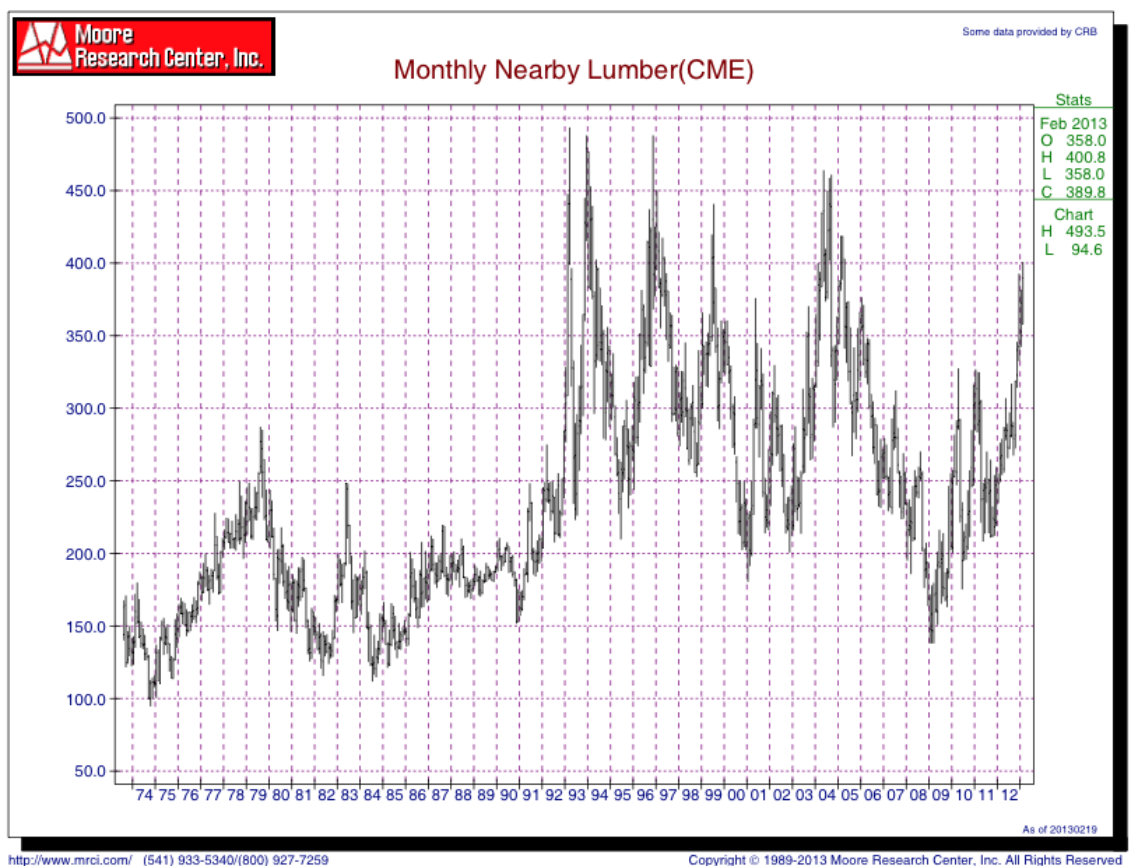

\section{Confusion in Execution}

Inflation and posited resource shortages meant that New Zealand forestry of the 1970s was attractively positioned as it sought to decommodify radiata pine (Pinus radiata) from being a knotty utilitarian material to a crucial component in an integrated supply chain delivering sophistication, whether in flooring, furniture, cabinet work, joinery or paneling [12]. The original idea, of pine outgrowing other species and transformed by pruning, was liberating [12]. By the end (in the early 1980s) it had moved from honest hope to a farrago of indubitabilities - too many optimistic assumptions. Consequently the sale of the State Forests was well-timed, leaving a luckless private sector to endure a long, slow fall of shareholder value $[13,14]$.

This does not deny the formidable achievement in establishing an enormous forest estate. From these $1.7 \mathrm{M}$ ha of forest (90\% radiata pine) flow NZ\$3.9 billion in exports and local employment for some 23,000 people; including $12.8 \mathrm{M} \mathrm{m}^{3}$ of log exports [15].

The shortcomings of clearwood lay not with the idea-it was elegant in its simplicity and alternatives appeared less viable, e.g., it did not seem possible to profitably produce structural timber with small knots from unpruned trees. The Forest Research Institute's Symposium Pruning and thinning practice in 1970 [16] established that small branches $(<50 \mathrm{~mm})$ necessitated unacceptably high stockings, e.g., $1.8 \mathrm{~m} \times 1.8 \mathrm{~m}$ in Kaingaroa (NZ's principal forested area).

The failure was not with the idea of clearwood. There was a mismatch between the strategic intent of Government, and an over-extended Forest Service, and an increasing reliance on a skeptical private sector. In 1990 van Wyk [17] observed that the management of NZ forests was not delivering enough high-grade wood (Table 1). By implication, profits from clearwood would not be able to support the large quantities of lower grade material. Whether decisions were determined by cash flow, or on some 
technical evaluation, over $50 \%$ of today's plantations are unpruned [15]. Instead the new default option appears to be structural lumber. New Zealand has recommodified its pine forests.

Table 1. Grade recovery for Pinus radiata, compared to those for traditional forest practices in Canada and Sweden [17]: unimproved pine generates a huge amount of low-grade wood. Upgrading that material is the immediate challenge.

\begin{tabular}{lccc}
\hline & Canada & Sweden & New Zealand \\
\hline Finishing (clears, dressings, cuttings) & $35 \%$ & $30 \%$ & $10 \%$ \\
Construction grades & $50 \%$ & $40 \%$ & $40 \%$ \\
Industrial/boxing & $15 \%$ & $30 \%$ & $50 \%$
\end{tabular}

With intensive silviculture the proportion of finishing could rise to $15 \%$ at most.

Whether NZ Forestry Inc. focuses on clearwood or structural lumber from radiata pine the obvious omission has been the lack of interest and progress on the corewood problem. Corewood, traditionally defined arbitrarily as the first 10 growth rings, accounts for some $50 \%$ of the lumber in a 25 year-old pine tree [18].

With $60+$ years of forest research and a billion dollars of state funding New Zealand has trees of greatly improved growth and form, but are wild and unimproved within. This is most evident in the corewood zone. A better definition of corewood might be clearwood with a cellulose microfibril angle of $35^{\circ}$ or more and a stiffness of $8 \mathrm{GPa}$ or less [19]. Such material is undesirable, both for structural (inadequate stiffness) and decorative (unstable and liable to distort/ warp) purposes [20]. The price differential (Table 2) between low-grade material that constitutes the corewood problem and utilitarian grades (framing and dressing) is greater than that between utilitarian grades and premium grades (engineering and finishing). Consequently more is to be gained improving wood quality in corewood than improving outerwood. Improving corewood stiffness should be the new mantra to replace our past obsession with basic density. Fortunately the technologies to achieve this have been developed. X-ray diffraction allows breeders to select and propagate families and clones having below average microfibril angle and so above average stiffness [20]. Contemporaneously practical acoustic tools permit rapid screening/ranking of standing trees or segregation of logs according to acoustic velocity [20], e.g., high stiffness $\operatorname{logs}$ (typically $>3.3 \mathrm{~km} / \mathrm{s}$ ) can be delivered to manufacturers of premium products such as LVL and trusses. With acoustic tools the longitudinal stiffness of the log is determined from the simple formula:

$$
\text { Modulus of elasticity }=(\text { acoustic velocity })^{2} \text { green density. }
$$

In air-dried wood the equation is the same except air-dry density replaces green density [20].

Table 2. Approximate prices (A \$) for structural lumber for premium, framing and utility grades. The same premium/discount applies broadly to board grades.

\begin{tabular}{ccc}
\hline Product & ${\text { Price } / \mathbf{m}^{\mathbf{3}}}$ & Premium/discount \\
\hline MGP12 & $\$ 475$ & $\$ 45$ or $11 \%$ \\
MGP10 & $\$ 430$ & \\
Pallets/boxing/dunnage & $\$ 220$ & $\$ 210$ or $49 \%$ \\
\hline
\end{tabular}


A study by the University of Canterbury (UC)-Carter Holt Harvey ( $\mathrm{CHH}$ ) of peeler cores [21] - the poorest wood in the tree-revealed the huge variation in corewood properties of radiata pine and the potential to improve fibre-length in kraft pulp (Figure 3).

Figure 3. Mean weighted fibre-length $(\mathrm{mm})$ found in 250 peeler cores - from butt logsfirst sorted into 18 acoustic velocity groups $\left(\mathrm{km}^{2} / \mathrm{s}^{2}\right)$ before being pulped [21].

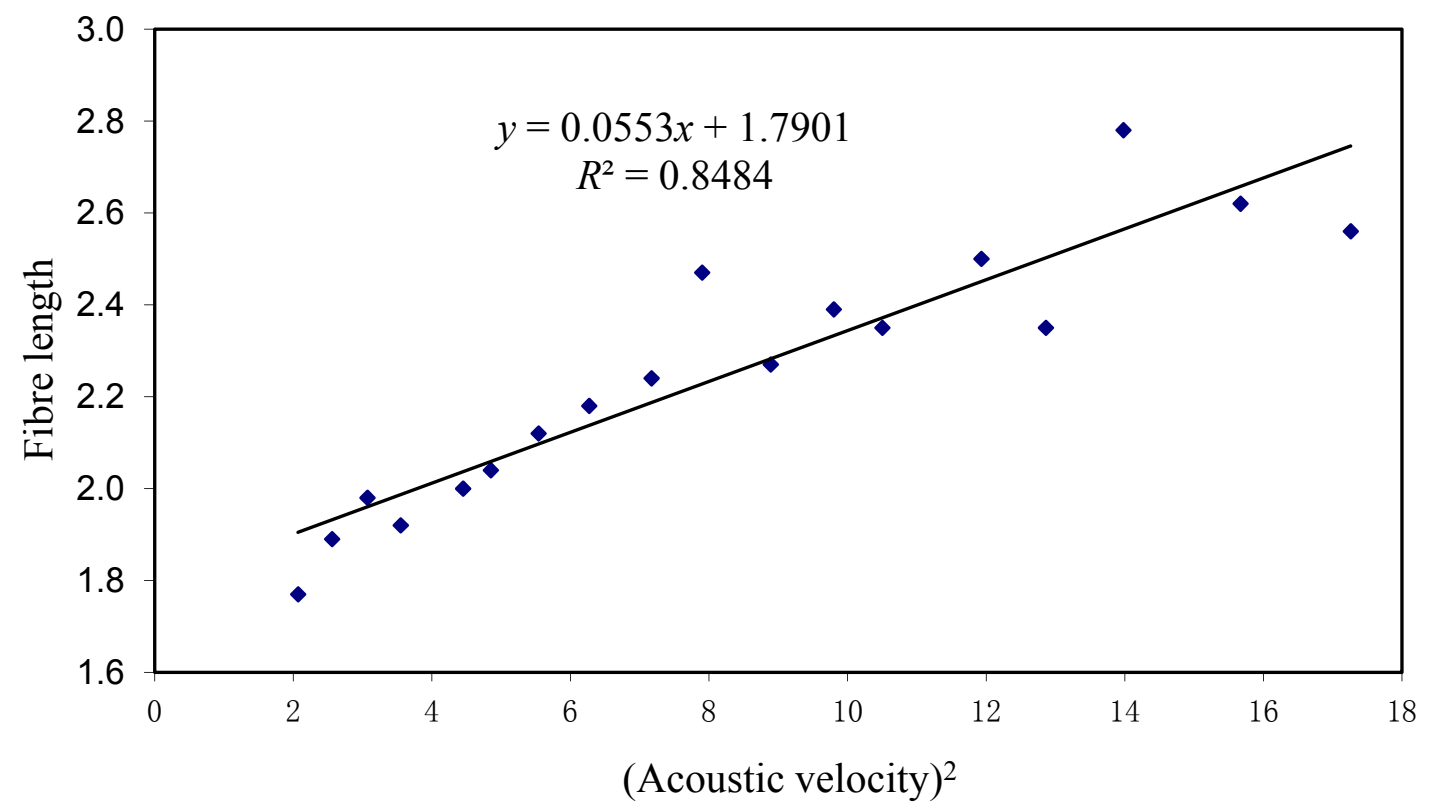

Subsequent, large $10,000+$ tonne batch trials allowed $\mathrm{CHH}$ to sort and produce a high-value fibre for fibre-cement products but the poorer quality of the residual fibre stock made segregation unviable. Similarly, a UC-Norske Skog (Boyer, Tasmania) study showed reduced energy consumption when mechanically pulping high acoustic velocity pulp logs [22]. In both instances benefits could not be captured by sorting the existing wood supply. Thus the priority should be to transform the intrinsic qualities (fibre length, stiffness and stability) of our future forests by breeding. Yet, amongst breeders the preference is for increased growth rate (and proportionately more corewood) ahead of improved wood properties [9]: quantity ahead of quality.

NZ log exports epitomize commodity trading. Over the last 50 years these have gradually refocused from Japan, to Korea, to China and now also to India, as each country has industrialized. Superior corewood properties (increased fibre length, stiffness and stability) would give New Zealand's $12.8 \mathrm{M} \mathrm{m}^{3}$ (US \$1.3 billion) log exports [15] some point of differentiation and preferred access during inevitable market downturns.

Instead, there has been an historic preoccupation with density. The NZ Forest Owners Association's science and innovation plan [9] endorses a modest increase in wood density - as if it were so obvious that it can be blandly asserted. There are three conflicting points. First, an increase in wood density must be at the expense of wood volume $\left(\mathrm{m}^{3} / \mathrm{ha} /\right.$ year). A tree produces a certain amount of photosynthate which can be allocated either as low density wood in a large diameter stem ( $\checkmark$ desirable) or as high density wood in a small diameter stem ( $\dashv$ less desirable)_you can include roots and branches if you wish. Second, one needs to decide whether to focus on improving the density of corewood $(\checkmark)$ or outerwood $(\dashv)$. There is only a modest correlation between the two [23]. The third 
point resolves around the question as to whether to increase the density of earlywood $(\checkmark)$ or of latewood $(\dashv)$. If one produced more or denser latewood then $P$. radiata will closer resemble the southern pines like $P$. taeda that is noted for its strongly contrasting wide bands of high density latewood and low density earlywood. That would be acceptable for structural timber but disastrous for clearwood exporters from New Zealand's colder southern regions of Otago and Southland who capitalize on their pale contrast-free pine that lacks distinctive latewood. Finally, as the proposal is to increase wood density by $10 \mathrm{~kg} / \mathrm{m}^{3}$ one might question whether this $2.5 \%$ gain is worth the effort. There is the proposition that density correlates with, and is highly leveraged to, other unspecified wood properties and this justifies the decision. Rather than indirect selection, via density, it is more logical to identify the best phenotypes for stiffness and stability at as early an age as possible [24].

In an original analysis Sorensson et al. [25] used an $8 \mathrm{GPa}$ corewood zone to illustrate the huge within-stand variability in the stiffness of radiata pine. They showed (Table 3 ) that individual trees achieved a stiffness of $8 \mathrm{GPa}$ (a conservative, but challenging value) at 3-metres height in the stem by ring 3 or 13 where considering the best and worst single tree in 100, or between ring 5 and 9 when considering best and worst single tree in five. In effect, they defined an acceptability threshold of $8 \mathrm{GPa}$ and proceeded to demonstrate that the undesirable, low-stiffness corewood zone $(<8 \mathrm{GPa})$ would correspond to the first 3 to 13 rings or the first 5 to 9 rings depending on the chosen percentile break points within the population. Individual trees look very different and more distinctly individual when evaluated in this way compared to the bland 10-ring corewood concept.

Table 3. Modeling of clearwood stiffness of Pinus radiata clones average growth [25].

\begin{tabular}{cc}
\hline Selected percentile class & Ring where timber achieves 8 GPa \pm std \\
\hline Top 1\% of population & $3.3 \pm 0.4$ \\
Bottom 1\% of population & $12.4 \pm 2.1$ \\
Top 20\% of population & $4.5 \pm 0.2$ \\
Bottom 20\% of population & $9.3 \pm 0.4$ \\
Average for all 1000 clones & $6.7 \pm 0.2$ \\
\hline
\end{tabular}

Expressing this strategy another way, Walker and Butterfield [26] concluded that reducing the microfibril angle in corewood by $5^{\circ}$ was a realistic breeding objective that would increase fibre length by about $0.5 \mathrm{~mm}$ and lift corewood stiffness by a whole grade. Improving corewood would reduce within-tree variability, another important industry goal [9].

Indifference can be buttressed by conservative practices - initial stockings of 2000 stems per hectare and longer rotations - have been advocated [27] to ensure a smaller, $<8 \mathrm{GPa}$, corewood zone and to control branch size. This would be an interim solution while persisting in planting unimproved trees.

The universal strategy of contradictions - of prolonged rotations, because faster growth means more low grade corewood; of higher stockings to suppress the otherwise enlarged corewood zone and so smaller trees and again a delayed harvest - is an outcome of the failure to focus breeding on the corewood properties of temperate softwoods.

Today's foresters have a general familiarity with these wood quality issues. However, too few understand the consequences for the poorest wood in the forest [28]. Critical to all analysis, structural timber grades are not determined by averages but by the weakest, low-strength extreme (5th percentile) 
in populations. While grading rules objectively define and then determine fitness for purpose they are conceived locally with local species in mind. Thus in New Zealand the principal structural grade MGP8 only satisfies the requirements for the lowest grade admitted by the EU and is below that permitted in Australia [29]. Even then, MGP8 is produced only from those NZ forests where companies are confident that they can source enough material that is sufficiently stiff to satisfy MGP criteria - despite the benefits of new lower grade thresholds [30]. The legal case regarding misgrading between the Commerce Commission and Carter Holt Harvey Limited under the Fair Trading Act highlighted the difficulty in extracting structural lumber from New Zealand's forests [31]. Fortunately Douglas-fir (Pseusosuga menziesii)—our most planted species after pine, 6\% vs. 90\% of the NZ plantation estate [15] - augments pine by supplying stiffer wood (MGP10 \& MGP12) for chords and lintels. From this perspective, Douglas-fir captures no new distinctive market: it is merely stiffer than radiata pine: also it is better suited to colder, high-altitude sites, but is grown on longer rotations.

Sitka spruce (Picea sitchensis) in Britain confronts similar issues with low-valued pallets, packaging and fencing absorbing two-thirds of production [32]. In this case the situation is exacerbated by cutting the highest value product, structural timber, from the poorest part of the tree, the corewood; and lower value products, pallets etc, from the best part of the tree, the outerwood [33].

The corewood problem in fast growing plantation softwoods has been recognized for many years $[34,35]$. The tragedy lies in the broad failure of wood technologists to accept that the principal cause of low stiffness, instability and short-fibre in corewood (high MFA rather than low density) and to demonstrate to tree breeders that there is less risk and more profit in upgrading the intrinsic corewood properties of future pine forests than blandly seeking faster growth. Thus tree breeding should involve a culling of the low stiffness tail within the unimproved population at an early age, $<2$ years [24].

Radiata pine is a versatile species: yet, doing everything does not mean doing everything well. The sector is asking it to perform across all markets, and why not as the breeders say that radiata pine is a plastic species. To succeed, the sector is asking geneticists to deliver a resource that will produce clearwood and structural lumber: a short internode for structural and long internode for furniture blanks; long-fibre for high-tear pulp lines such as fibre cement; drought resistance for east coast regions of New Zealand; salt tolerance for the Murray-Darling river basin in Australia; biofuels etc. The alternate approach is to eschew the broad versatility of pine - it always was a mirage - and instead promote alongside radiata pine select species that in particular niche markets will outperform anything that might evolve with radiata pine.

What would alternatives [species] do that radiata pine could not do also? Not very much. Radiata pine has deficiencies in some areas-appearance, surface hardness, and in some extremely demanding situations such as tool handles-but in many other respects it is itself a high quality species (Quote from 1979).

New Zealand can take pride in producing a major commodity like radiata pine, but the true contrast that should be drawn is between a viable, utilitarian species that captures value by integrating itself within a supply chain (let us call it the Tenon strategy [36], after New Zealand's largest publicly listed forest products company) and other species that position themselves to supplant the prized timbers of the tropics-ebony (Diospyros spp.), mahogany (Swietenia spp.; Khaya spp.), rosewood (Dalbergia 
spp.) and teak (Tectona grandis) — or match in their desirability Appalachian cherry (Prunus serotina), Italian walnut (Juglans regia) and French oak (Quercus robur).

If the profits (and their volatility) of pine forests struggle to meet the expectations of corporate Chief Financial Officers, it is hard to see down-stream processing doing better. Asian businesses have learnt to produce better products with less material and at a lower cost, so NZ wood processors will struggle unless integral to unique, dedicated supply chains: supply chains that will be subject to the wishes of local Asian partners and the constraints imposed by state power with its close-knit bureaucracy (half protective, half inhibitory). It was always thus; 200 years ago under the Ch'ing state bureaucracy saw the exercise of that power as coming ahead of profits or capitalism [37].

Incumbents have a problem creating anything that would compete with what they are already doing. It is the endowment effect: overvaluing what is already theirs. Thus the NZ Forest Owners Association does not see sponsoring alternative species as its responsibility [9], and...

It must be remembered that there is nothing more difficult to plan, more doubtful of success, nor more dangerous to manage, than the creation of a new system. For the initiator has the enmity of all who would profit by the preservation of the old institutions and merely lukewarm defenders in those who would gain by the new ones (The Prince, Niccolò Machiavelli).

Such discontinuities are not breaks with the past but the logical consequences of preceding events.

\section{Culture, Aesthetics and Minimalism}

Despite capturing the full genetic diversity of radiata pine from within its natural habitat in North America and despite years of traditional tree improvement in New Zealand, it remains unimproved with regard to wood properties. The same is true of all plantation species grown for solid wood products. Consequently established species come out of the starting gate alongside all other species. Ironically, since genetic diversity is considerable in all tree species, significant wood quality gains can be made quickly and cheaply working with a relatively small number of families - say 100+ families - so considerable improvements in wood quality are as immediately achievable with a modest breeding population of a little known but promising species as can be achieved by well-established plantation species.

In searching for quality, all plantation species that NZ currently grows are best categorized as artisanal so, while one would be foolish to slavishly anticipate consumer taste 30 years hence, New Zealand is obliged to place an informed bet on something distinctively different which we see to be elite naturally-durable eucalypts. Eucalypts, like all hardwoods do not form corewood. They get off to a far better start with regard to wood quality. The wood in young hardwoods is intrinsically superior to that of softwoods. Consequently, hardwoods are better suited to producing good timber on short rotations: they can be harvested in 12-18 years rather than 24-30 years with softwoods.

Any species trialed today will be marketed in a world with 1500 million new middle-class Asians - at a time when the GDP of China and India will be greater than that of the rest of the world [38]. NZ forestry can hardly be more complacent if it expects to remain unchanged by its encounter with such ambitions. 
The earliest European visitors to China were all agreed that it was the richest country in the world, that China was an alternative First World nation.

For the Chinese, clothing and housing formed a continuum. For Europeans, they formed a polarity, especially when fashion began to distinguish indoors and outdoors, wear and overwear. If textiles were a bigger rival to bricks and mortar in China than in Europe, so too was furniture. In the sixteenth century, European furniture was still comparatively primitive and cumbersome. In China, on the other hand, the period 1550 to 1735 has been described as the golden age of classical furniture. Light and elegant, it made use of new, imported tropical hardwoods, notably the huang-hua li, Dalbergia, from Vietnam and Hainan. Craig Clunas, in his account of Chinese connoisseurship in this period, notes that, 'fine clothes and fine furniture were an important part of the presentation of an upper-class persona of the world.' Chinese furniture of this period anticipated not only Chippendale, Hepplewhite and Sheraton in its sophistication, but Maples, Heals and Habitat in its functionalism. (Summary of Adshead, p. 110 [39]).

Such differences in temporal orientation highlight practical issues, e.g., over what period should debt be amortized? What value should be placed on liquidity? More than food and dress, housing involves the future. In this option, Europe and China made different choices. Europe chose a high outlay by building with stone and low subsequent maintenance. China chose a low initial outlay and high subsequent maintenance: timber was favoured in construction, despite constrained accessible supply. This preference arose, in part, because China is vulnerable to natural disasters that have discouraged the outlay of capital: typhoons and flooding, also earthquakes in the north.

Two features of the housing market stand out - the life cycle and the floor area. In much of Asia the life of a typical house has been about 30 years. For example The Economist [40] reported:

In post-war Japan land has value but buildings do not. The law separates the ownership of the land and the structure, so the two are distinct in Japanese minds... After around 30 years homes are demolished for new ones to spring up [41]. Because the lifetime of houses is so short, cheap construction materials are used [Does that explain the ready market for radiata pine?] and the buildings are not maintained. There is no tradition of do-it-yourself home upkeep. Just as there is no interest in secondhand-furniture or clothes among the sanitation-obsessed Japanese, so too home-owners prefer to build anew rather than to refurbish the old.

The proportion of old houses ( $>40$ years) in Japan's housing stock is inevitably small after the disruption of war, while the urgent necessities of the 1950s-1970s overrode exemplary building practices - the use of sea sand in multistorey complexes resulted in corrosion of the reinforcing rods. Also, high humidity means a greater risk of decay and termites in Japanese houses.

More pertinent is the floor area of a typical Asian house, at most 80-100 $\mathrm{m}^{2}$ [42]. After WW2 American families with 1-2-3 children lived in similarly sized $100 \mathrm{~m}^{2}$ homes (as in New Zealand) since then the living area has increased three-fold while the occupancy rate has fallen. It is unlikely that that trend can be replicated in Asian cities. 
Once taste supersedes basic needs the new middle-class in Asia will place greater emphasis on the quality of the interior finishings and furnishings, flooring and paneling; and more so as they switch from bling to the real thing. Society is moving beyond imitations and fakes. Beyond their superficiality and functionalism material goods can be endowed with deeper meaning through symbolismplenipotentiary rather than ambassadorial—with, for example, the dragon representing the Emperor's Authority, his protection and wisdom. In the same way a BMW is more than a car. It applies to Keat's Greek Urn with its whole system of literary resonances. The plenipotentiary power of fine timbers is considerable, hence the anger when cheated...

Doris Phua (DaVinci) also said that there is a long-standing misunderstand at present, that being "all made in Italy furniture must be 100\% solid wood, but actually the essence of Italian furniture lies in its design, materials, and innovation”. In any other context this quote would be a brilliant succinct truth.

The company claimed its furniture was made in Italy, whereas some was alleged to have been manufactured using medium density fibreboard in Chinese factories, and exported to the Shanghai Waigaoqiao Bonded Zone, and later imported back to the company's warehouses in Shanghai [43].

Current Asia's household expenditure is more resource-intensive compared to that in mature economies, and this will grow demand for forest commodities for at least another 10 years. Beyond that, even if the limits to growth are overstated [10], frugality is likely to be relieved by aesthetic and ethical virtues that cannot be encapsulated by species currently grown in New Zealand. Consumerism in the future will be less about acquisition of more, as discerning what is better. China accounts for $6 \%$ of the world's consumer spending but $20 \%$ of global sales of luxury goods [44]. This marks a significant progression from utility today towards prestige tomorrow-both its public face and personal hedonistic enjoyment [45].

\section{Stiff, Naturally Durable Eucalypts: Everything That Radiata Pine Is Not}

New Zealand has failed to develop a large eucalypt estate, in marked contrast to other Southern Hemisphere countries both in temperate and sub-tropical regions. However, those countries with their magnificent hardwood natural forests have grown eucalypts principally for pulp and paper, rather than for sawn timber. With pulpwood, New Zealand has no specific advantage and would have little prospect of competing on equal terms.

10 years ago wine growers in Marlborough at the top of the south island of New Zealand sought strong, naturally-durable posts to replace copper-chrome-arsenate treated radiata pine posts. Being largely corewood these pine posts broke during machine harvesting costing the industry an estimated NZ\$36 million/year to replace (ca. \$40/post in the ground). Replacing these with strong, naturally-durable posts would mean fewer posts failing and would avoid potential leaching of heavy metals to groundwater; there would be no dumping of hazardous waste in secure landfill; and no consumer backlash against NZ wine exports from "mis-perceptions" of contamination [46]. Dryland eucalypts were the obvious alternative because the Australian Low Rainfall Tree Improvement Group (ALRTIG) had identified some candidate species (displaying drought tolerance, good growth and form, strength and durability) and ALRTIG had an active breeding programme $[47,48]$. 
For New Zealand this strategy has a broader, local appeal with assured demand for utility cross-arms, sleepers (both for rail and landscaping), for wharf/marina decking and indoor flooring and outdoor decking; and in parallel there would be the enormous Asian market.

New Zealand would enjoy a comparative advantage in that low-value, marginal, pastoral dryland could be used to supply high-value timber to markets embracing those additional 1500 million middle-class in Asia who by 2050 will have a standard of living similar to Europe's today [38]. Thus in the long-term one could envisage $100,000+$ ha spread as a mosaic of woodlots on three million ha of drylands ( $<900 \mathrm{~mm}$ rainfall) as alternatives to coveted tropical timbers [49]. These could be trademarked on Asian markets as NZ rosewood (blood-red coloured) for China, NZ teak (honey coloured) for India and compete by virtue of excellence and scarcity — and at less risk of obsolescence or competition - while Asia and technology keep lowering the costs of almost everything else [50].

Demand in Asia is forecast to rise, at least in line with GDP, which at 4\% pa until 2050 would equate to a 4-fold increase. At the same time supply from the tropical rainforest is decreasing: Asia produced $130 \mathrm{M} \mathrm{m}^{3}$ of hardwood sawlogs in 1989, against $98 \mathrm{M} \mathrm{m}^{3}$ in 2010 [51], projected to fall to about $45-55 \mathrm{M} \mathrm{m}^{3} /$ year by 2050 . The price of imported tropical sawn wood to Australia has increased ca. $2 \%$ pa from US $\$ 380$ to $\$ 940 / \mathrm{m}^{3}$ over the last 20 years, reflecting this constraint on supply. Plantations in the tropics and sub-tropics are largely for pulpwood. Statistics of the area of hardwood plantations for sawlogs are hard to find. In 1995 there were $0.15 \mathrm{M}$ ha of mahogany, $0.6 \mathrm{M}$ ha of rosewood and 2.2 $\mathrm{M}$ ha of teak plantations [52]: these are the only species defined by FAO as "luxury" [52]. Of these only teak is characterized by FAO as being a globally emerging forest resource, now with over 3.6 $\mathrm{M}$ ha [53], and so potentially able to replace a little of the dwindling natural resource.

Successful forest management needs the pre-essentials of healthy, straight, vigorous trees without which there would be no access to markets. Past disillusionment in New Zealand with eucalypts has been as much due to an exaggerated focus on forestry problems. Species that are $5 \times$ more valuable can afford to be less productive (itself debatable) and somewhat intractable (but one can never be indifferent to pests and diseases). However, it is the distinctive features (Figure 4) of the wood (colour, figure, hardness, odour and stability) that allow a species to make it — or not—on the world stage. To capture a share of high-value markets a breeding programme must include wood quality assessments that will be very different to those for radiata pine. One needs to exaggerate desired features such as colour, early heartwood formation, odour and low growth stress, as well as the ability to coppice [50]. Indeed, early characterization and intense selection from highly variable, unimproved new species will build the confidence of growers and exclusivity for their customers. With such species New Zealand should be in a position to supply the universal needs that others can take and translate into local desires; and at the same time have niche resource to complement radiata pine on world markets. 
Figure 4. (a) Spirits on "rosewood". A laminated board from old-growth riverine E. camuldulensis from Mildura on the New South Wales/Victoria border in Australia; (b) Feeding on dreams. Laminated "NZ teak" from New Zealand grown E. bosistoana; (c) The symbolism in the fretwork in this Imperial table reflects cultural tradition and status. Fine modern interpretations of older styles still need elite woods.

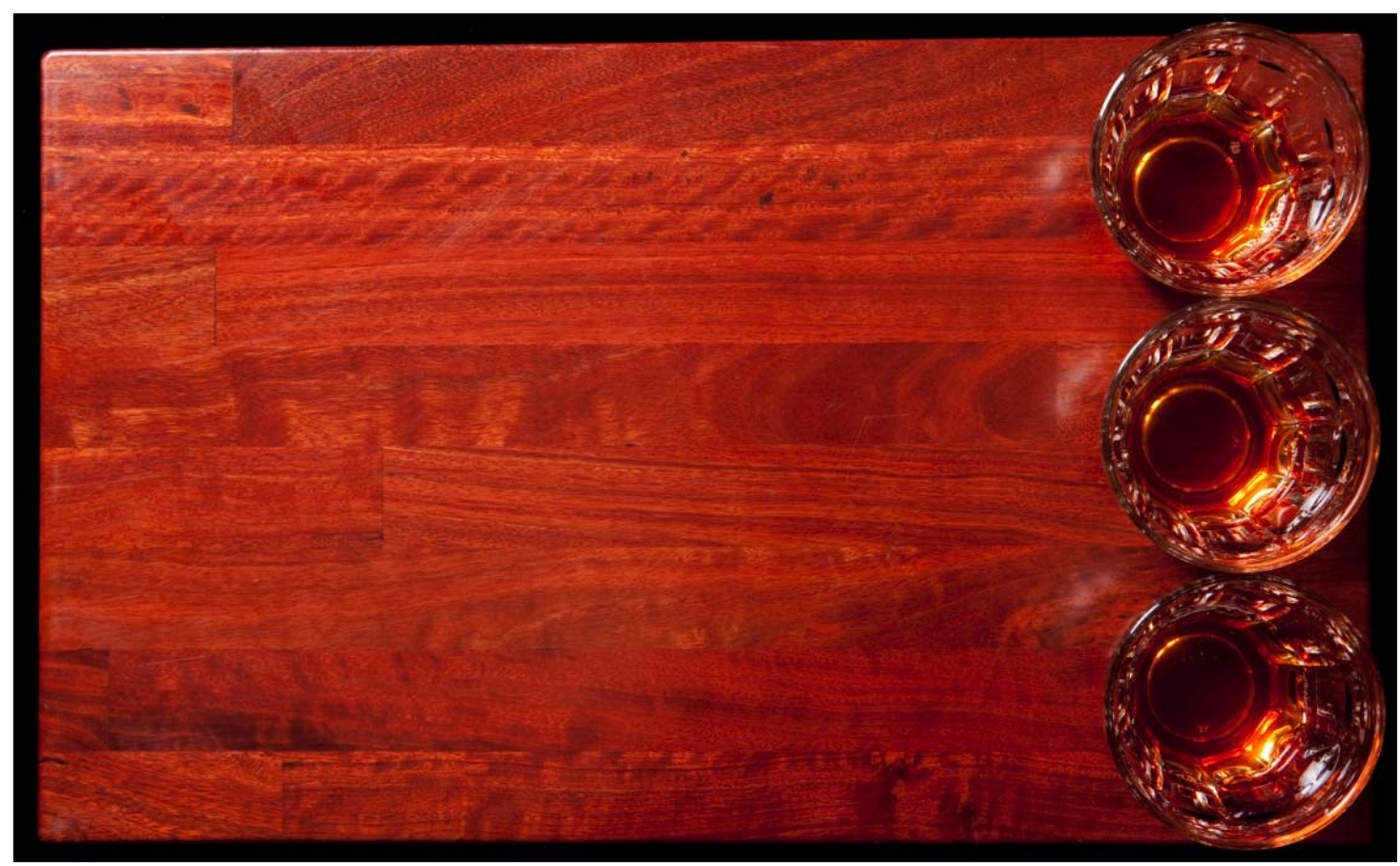

(a)

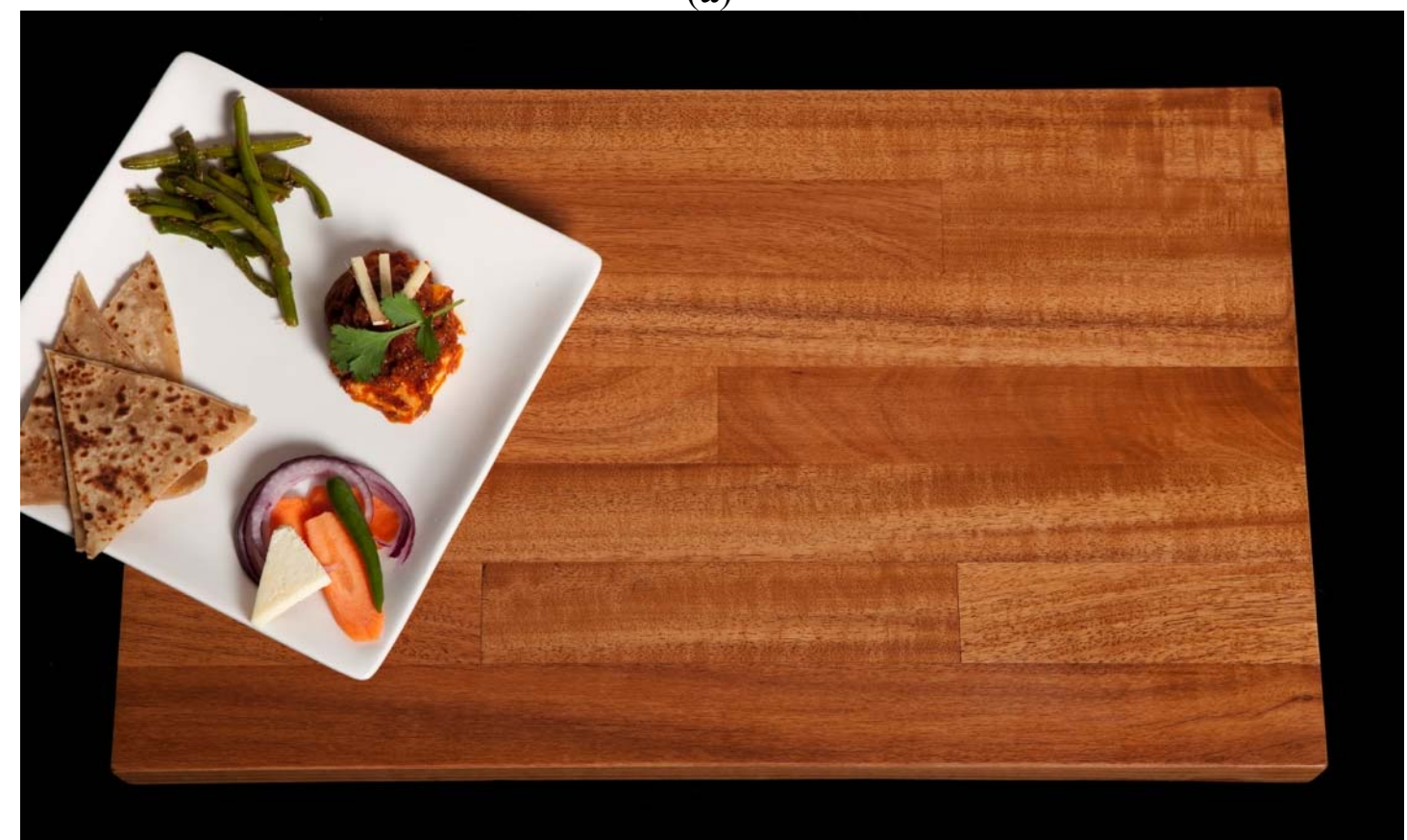

(b) 
Figure 4. Cont.

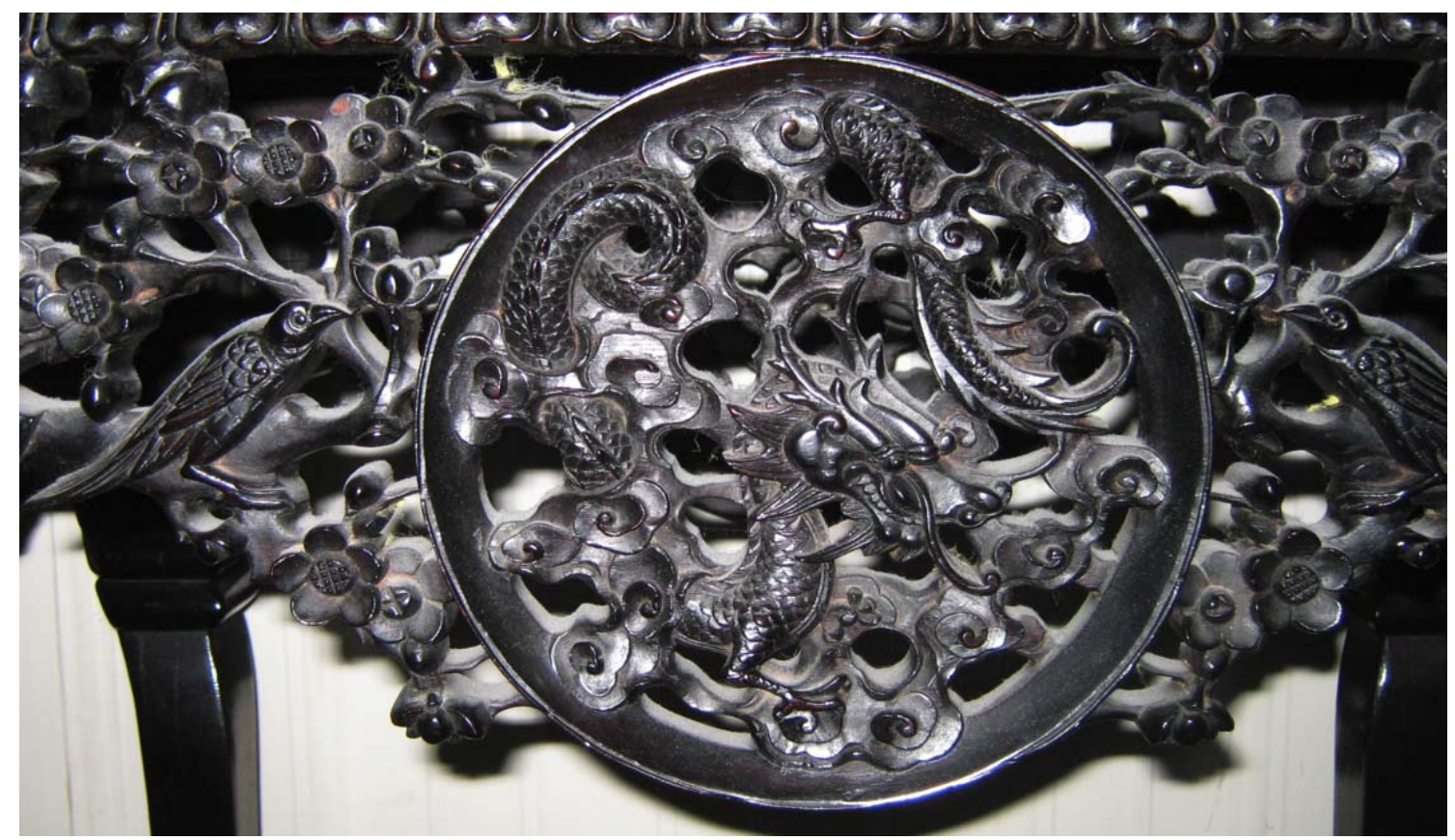

(c)

\section{Summary}

New Zealand needs a two-pronged strategy of: (1) eliminating the low-quality tail (the corewood problem) in radiata pine to deliver longer kraft pulp fibre, lower energy mechanical pulp, and stiffer, more stable timber - all readily achievable [25,26]; and (2) the creation of a highly coloured, naturally-durable eucalypt resource suited to drylands that mimic in their qualities those of the most valuable tropical hardwoods [45] - to compete on innovation and excellence rather than price, undergirded by scarcity and environmental constraints.

While the focus here has been on New Zealand forestry, the ideas and approaches can be applied elsewhere.

\section{Acknowledgements}

The discussion on China draws heavily on Adshead [39]. His ideas are too numerous to reference and acknowledge individually. For many years the late Professor Sam Adshead was in the History Department at the University of Canterbury.

\section{Conflict of Interest}

The author declares no conflict of interest.

\section{References and Notes}

1. Meadows, D.H.; Meadows, D.L.; Randers, J.; Behrens, W.W. The Limits to Growth: A Report for the Club of Rome's Project on the Predicament of Mankind; Universe Books: New York, NY, USA, 1972. 
2. Moore, N. New life from old farmland. New Sci. 1987, 115, 50-52.

3. Corron, N.; He, X.-Z.; Westerhoff, F. Butter mountains, milk lakes and optimal price limiters. J. Econ. Dyn. Control 2005, 27, 503-531.

4. National Exotic Forest Description; Ministry of Agriculture and Forestry: Wellington, New Zealand, 2011.

5. Carle, J.; Vuorinen, P.; del Lungo, A. Status and trends in global forest plantation development. For. Prod. J. 2002, 52, 3-13.

6. Walker, J.C.F. Finding a brighter future in commodities. N. Z. J. For. 2003, 48, 29-31.

7. Walker, J.C.F. Clausewitz on forestry. N. Z. J. For. 2007, 51, 34-37.

8. A raw deal for commodities. The Economist 1999, 351, 85-86.

9. New Zealand Forestry Science and Innovation Plan; Forest Owners Association (FOA): Wellington, New Zealand, 2012.

10. Gilding, P. The Great Disruption; Bloomsbury Press: London, UK, 2011.

11. Ridley, M. The Rational Optimist; Fourth Estate: London, UK, 2010.

12. Bunn, E.H. The nature of the resource. N. Z. J. For. 1981, 26, 162-199.

13. Bilek, E.M.; Horgan, G.P. Organizational and Administrative Challenges Involving Large-scale Transfer of Public Assets to the Private Sector: New Zealand's Experience. In Proceedings of the 19th Congress International Union of Forest Research Organisations (IUFRO), Montreal, Canada, 5-11 August 1990; IUFRO: Vienna, Austria, 1990.

14. Bilek, E.M.; Horgan, G.P. The Challenges of Privatization: New Zealand's Experience with Forestry. In Proceedings of the IUFRO International Conference on Integrated Sustainable Multiple-Use Forest Management under the Market System, Pushkino, Russian Federation, 6-12 September 1992; IUFRO: Vienna, Austria, 1992.

15. New Zealand Plantation Forest Industry: Facts and Figures; Forest Owners Association (FOA): Wellington, New Zealand, 2012.

16. James, R.N. Pruning and Thinning Practice. In Proceedings of the FRI Symposium No. 12, Rotorua, New Zealand, 16-20 March 1970; Forest Research Institute: Rotorua, New Zealand, 1970.

17. Van Wyk, L.J. An Overview of Value Added Strategies. In Proceedings of the Forest Industry Engineering Association (FIEA) Conference, Technologies Towards 2000, Rotorua, New Zealand, 31 May 1990.

18. Cown, D.J. Corewood (juvenile wood) in Pinus radiate-Should we be concerned? N. Z. J. For. Sci. 1992, 22, 87-95.

19. Megraw, R.Q.; Leaf, G.; Bremer, D.; Longitudinal shrinkage and microfibril angle in loblolly pine. In Proceedings of IAWA/IUFRO Workshop on Microfibril Angle in Wood, Westport, New Zealand; 11-13 November 1997; Butterfield, B., Ed.; University of Canterbury: Christchurch, New Zealand, 1998; pp. 27-61.

20. Huang, C.-L.; Lindström, H.; Nakada, R.; Ralston, J. Cell wall structure and wood properties determined by acoustics-A selective review. Holz Roh Werks 2003, 61, 321-335.

21. Albert, D.J.; Clark, T.A.; Dickson, R.L.; Walker, J.C.F. Using acoustics to sort radiata pine pulp logs according to fibre characteristics and paper properties. Int. For. Rev. 2002, 4, 12-19.

22. Bradley, A.; Chauhan, S.S.; Walker, J.C.F.; Banham, P. Using acoustics in log segregation to optimise energy use in thermomechanical pulping. Appita J. 2005, 58, 306-311. 
23. Harris, J.M.; James, R.N.; Collings, M.J.R. Case for improving wood density in radiata pine. N. Z. J. For. Sci. 1976, 5, 347-354.

24. Apiolaza, L.A. Very early selection for solid wood quality: Screening for early winners. Ann. For. Sci. 2009, 66, 601-671.

25. Sorenesson, C.; Nepveu, G.; Kimberley, M. Intra- and Inter-tree Modelling of Wood Stiffness of Clears of Age-10 Radiata Pine Clones, and Simulated Response of Stiffness to Increased Genetic Gain Selection Intensity. In Proceedings of the IUFRO Conference S.01-04, Connection between Silviculture and Wood Quality through Modelling, Harrison Hot Springs, Canada, 10-15 September 2002; pp. 104-117.

26. Walker, J.C.F.; Butterfield, B.G. The importance of microfibril angle for the processing industries. N. Z. J. For. 1995, 40, 34-40.

27. Mason, E. Influences of silviculture, genetics and environment on radiata pine corewood properties: Results from recent studies and a future direction. N. Z. J. For. 2008, 53, 26-31.

28. Walker, J.C.F. Breeding, getting the most from radiata pine. N. Z. Tree Grower 2010, 31, 13-14.

29. Moore, J.R. Growing fit-for-purpose structural timber: What's the target and how do we get there? N. Z. J. For. 2012, 57, 17-24.

30. Gaunt, D. If you are not winning, change the rules. Wood Process. Newsl. Sawmilling 1998, 23, 3-4.

31. Commerce Commission New Zealand. Available online: http://www.comcom.govt.nz/mediareleases/detail/2011/commerce-commission-settles-timber-claim-against-carter-holt-harvey (accessed on 9 November 2011).

32. Macdonald, E.; Hubert, J. A review of the effects of silviculture on timber quality of Sitka spruce. Forestry 2002, 75, 107-138.

33. Moore, J.R. Wood Properties and Uses of Sitka Spruce in Britain; Forestry Commission; Research Report; Forestry Commission: Edinburgh, UK, 2011.

34. Megraw, R.A. Wood Quality Factors in Loblolly Pine: The Influence of Tree Age, Position in Tree, and Cultural Practice on Wood Specific Gravity, Fiber Length, and Fibril Angle; TAPPI Press: Atlanta, GA, USA, 1985.

35. Senft, J.F.; Bendsten, B.A.; Galligan, W.L. Weak wood: Fast grown trees make problem lumber. J. For. 1985, 83, 477-484.

36. Annual Report; Tenon Ltd.: Auckland, New Zealand, 2011; p. 4; "Our logistics platform combines this internally manufactured product together with extensive third-party sourcing across three continents... This aspect of the business has become more complex as the third-party sourced volume sold through our distribution business has grown over time. To put some numbers to this third-party sourcing growth, today Taupo (New Zealand) manufactured product represents less than $10 \%$ of our total US distribution sales".

37. Braudel, F. Civilization \& Capitalism 15th-18th Century: Vol 2, the Wheels of Commerce; Translated Sian Reynolds Collins: London, UK, 1982.

38. Asia 2050: Realizing the Asian Century; Asian Development Bank (ADB): Manila, Philippines, 2011.

39. Adshead, S.A.M. Material Culture in Europe and China, 1400-1800: The Rise of Consumerism; MacMillan Press Ltd.: London, UK, 1997. 
40. Japan's property market: Building wealth. The Economist 2008, 386, 61-62.

41. The Director's Notes quotes a lifespan of a house in Japan to be currently 35 years. Cintrafor News, University of Washington: Seattle, WA, USA, 2010.

42. China Wood and Building Materials Market; Cintrafor, University of Washington: Seattle, WA, USA, 2002.

43. The New York Times. Available online: http://www.nytimes.com/2011/07/19/business/global/ chinese-upset-over-counterfeit-furniture.html? (accessed on 12 February 2012).

44. Fakes and status in China. The Economist 2012, 403, 74.

45. Wong, N.Y.; Ahuvia, A.C. Personal taste and family face: Luxury consumption in Confucian and Western Societies. Psychol. Market. 1998, 15, 423-441.

46. Millen, P. NZ Dryland Forests Initiative: A Market Focused Durable Eucalypt R\&D Project. In Revisiting Eucalypts 2009; Apiolaza, L., Chauhan, S., Walker, J., Eds.; University of Canterbury: Christchurch, New Zealand, 2009; pp. 57-74.

47. Bush, D. Selecting and Breeding Eucalypts for Natural Durability. In Proceedings of Developing a Eucalypt Resource-Learning from Australia and Elsewhere, Blenheim, New Zealand, 3-4 November 2011; Walker, J., Ed.; University of Canterbury: Christchurch, New Zealand, 2011; pp. 125-136;.

48. Harwood, C. Introductions-Doing It Right. In Proceedings of Developing a Eucalypt Resource-Learning from Australia and Elsewhere, Blenheim, New Zealand, 3-4 November 2011; Walker, J., Ed.; University of Canterbury: Christchurch, New Zealand, 2011; pp. 43-54.

49. New Zealand Dryland Forests Initiative. Available online: http://www.nzdfi.org.nz (accessed on 12 February 2012).

50. Apiolaza, L.; Mason, E.; McConnochie, R.; Millen, P.; van Ballekom, S.; Walker, J. New Zealand Dryland Forests Initiative-Learning from Others. In Proceedings of Developing a Eucalypt Resource-Learning from Australia and Elsewhere, Blenheim, New Zealand, 3-4 November 2011; Walker, J., Ed.; University of Canterbury: Christchurch, New Zealand, 2011; pp. 147-158.

51. Annual Report of Forest Statistics; Food \& Agriculture Organization (FAO): Rome, Italy, 2010.

52. Promotion of Valuable Hardwood Plantations in the Tropics. A Global Overview; Report based on the work of F. K Odoom, Forest Plantation Thematic Papers, Working Paper 4; Forest Resources Development Service, Forest Resources Division, Food \& Agriculture Organization (FAO): Rome, Italy, 2001; unpublished.

53. Kollert, W.; Cherubini, L. Planted teak forests - A globally emerging resource. Presented at International Forestry Conference, Organized by Centro Agronómico Tropical de Investigación y Enseñanza (CATIE)/FAO/International Teak Information Network (TEAKNET), San José, Costa Rica, 31 October-5 November 2011.

(C) 2013 by the authors; licensee MDPI, Basel, Switzerland. This article is an open access article distributed under the terms and conditions of the Creative Commons Attribution license (http://creativecommons.org/licenses/by/3.0/). 